\title{
ENFORCING NONJUSTICIABLE RIGHTS IN INDONESIA
}

\author{
Andy Omara* \\ Universitas Gadjah Mada School of Law, Yogyakarta, Indonesia \\ andy.omara@mail.ugm.ac.id
}

Received: 10 July 2019 | Revised: 20 April 2020 | Accepted: 29 October 2020

\begin{abstract}
A debate over which branch of government is the most appropriate institution to deal with economic and social rights is far from ended. Is it the legislature which is democratically elected or the unelected Court that should determine the enforcement of economic and social rights? Problems pertaining to the lack of legitimacy and competence often come up when the Court is involved in determining economic and social rights. These problems arise because a court is not democratically elected and is not equipped with necessary tools to deal with such a complex issue in economic and social rights. However, others believe that the Court's involvement in determining economic and social rights can strengthen democracy since the Court may enforce matter that is not sufficiently addressed by the lawmaker. This paper will address the above issue in context of Indonesia. Should the Court involve in protecting economic and social rights? If so, how far the Court can go to determine economic and social rights? This paper acknowledges that economic and social rights are a broad and complex topic. Therefore, this paper limits the discussion by analyzing four selected judicial rulings which have significant impact in the protection of economic and social rights in Indonesia i.e. the judicial review cases on Electricity Law, Water Resources Law, National Education System Law and National Budget Law. This paper argues that it is necessary for the Court to involve in determining economic and social rights, especially when the lawmaker does not sufficiently address issues related to economic and social rights in its legislative product. The Court may fill the gaps in the protection of Economic and Social rights.
\end{abstract}

Andy Omara is an Associate Professor of Constitutional Law at Department of Constitutional Law, Universitas Gadjah Mada (UGM) School of Law, Yogyakarta, Indonesia. He graduated from Universitas Gadjah Mada (S.H.), University of Melbourne (MPub\&IntLaw.) and University of Washington (Ph.D.). 
The Court roles in this context, however, potentially encroach the authority of other branches of governments i.e. the executive and the legislative. Therefore, the Court roles should be carefully and strategically conducted so that it does not infringe the jurisdiction of the government and the lawmakers.

Keywords: Constitutional Court, Economic, Indonesia Social Rights.

\section{INTRODUCTION}

Whether economic and social rights are judicially enforceable has been questioned since the introduction of two sets of rights: civil and political rights and economic, social and cultural rights. Judicially enforceable or commonly called justiciability refers to the ability to claim a remedy before an independent body when a violation of a right has occurred or is likely to occur. ${ }^{2}$ It means the extent to which a matter is suitable for judicial determination. ${ }^{3}$ Justiciability implies access to mechanisms that guarantee recognized rights. ${ }^{4}$ Justiciable rights allow right-holders a legal course of action to enforce them, whenever the duty-bearers do not comply with their duties.5

There is opinion that civil and political rights (e.g. right to vote, right to form association) are justiciable whereas economic and social rights (e.g. right to education, right to health, right to clean water) are not. ${ }^{6}$ This essentially means that civil and political rights can be judicially enforced, while economic and social rights cannot. This assertion does not reflect comprehensive perspectives.

\footnotetext{
"Key concepts on ESCRs-Are economic, social and cultural rights fundamentally different from civil and political rights?" United Nations Human Rights, Office of the High Commissioner, accessed January 27, 2020, https:// www.ohchr.org/EN/Issues/ESCR/Pages/AreESCRfundamentallydifferentfromcivilandpoliticalrights.aspx. Universal Declaration of Human Rights of 1948 also contained economic social and cultural rights; international covenant on economic social and cultural rights was adopted in 1966 and entered into force in 1976. See also Graig Scott and Patrick Macklem, "Constitutional Ropes of Sand or Justiciable Guarantees? Social Rights in a New South African Constitution," University of Pennsylvania Law Review 141, no.1 (November 1992): 18.

2 International Commission of Jurist (ICJ), "Court and The Legal Enforcement of Economic Social and Cultural Rights: Comparative Experience of Justiciability" (A Report, International Commission of Jurist Publisher, 2008$), 6$.

Scott and Macklem, "Constitutional Ropes", 17.

Scott and Macklem, "Constitutional Ropes", 17.

Scott and Macklem, "Constitutional Ropes", 17.

6 While the ESC Rights are grounded in UDHR, ICESCR and CRC (particularly on right to education) there are different attitude on how countries address the right to education. See Jody Heymann, Aleta Sprague and Amy Raub, Advancing Equality: How Constitutional Rights Can Make a Difference Worldwide (Oakland: University of California Press, 2020), 201-202.
} 
In practice, whether or not economic and social rights are justiciable is a matter of choice. Some countries constitutions such as the US Constitution and the Ireland Constitution ${ }^{7}$ recognize economic and social rights as non-justiciable while other country constitutions such as the Constitution of the Philippines considers economic and social rights as justiciable rights. ${ }^{8}$

In line with justiciable and non-justiciable rights category, this paper will specifically examine the justiciability of economic and social rights in Indonesia. Does the amended Constitution of Indonesia acknowledge economic and social rights as justiciable rights? If so, to what extent the involvement of the Constitutional Court in protecting these rights? The paper will examine the roles of the Constitutional Court in deciding economic and social rights cases. In doing so, the paper will analyse judicial review cases on ES rights determined by the Indonesian Constitutional Court. The paper argues that while there are no explicit constitutional provision states that economic and social rights justiciable, the Constitutional Court, through its decisions, determine that economic and social rights are justiciable. The Court rulings play significant roles in protecting economic and social right, particularly when the government reluctant to enforce such rights. However, it may potentially create problems if the Court is lack of necessary information and competence.

Part II will briefly describe the development on the justiciability of economic and social rights and clarify the misconception about the dichotomy between justiciability of civil and political rights and economic and social rights. Part III will discuss the jurisprudential development of the justiciability of economic and social rights. Part IV will discuss different approaches adopted by some countries, including Indonesia in protecting of economic and social rights. Part $\mathrm{V}$ will specifically analyse the Indonesian Constitutional Court's approach in protecting economic and social rights. The analysis will be conducted through a careful examination of four Constitutional Court rulings, i.e. Court decision on Electricity Law, Water Resources Law, National Educational System Law

\footnotetext{
Article 45 of the 1937 Ireland Constitution, Directive Principles of Social Policy.

Article VII of the 1987 Philippines Constitution. The duty of court of justice to settle actual controversies which are legally demandable and enforceable.
} 
and National State Budget Law. Three different models on the protection of ES rights such as judicially enforceable rights, a tool to test the reasonableness of government policy-making and non-justiciable policy guidelines will be used to indicate the Court approach.9 These models can appropriately explain the Indonesian Court attitude in settling judicial review cases related to ES Rights. Finally, Part VI will provide-conclusion.

\section{THE DEVELOPMENT OF THE JUSTICIABILITY OF ECONOMIC AND SOCIAL RIGHTS}

In the past, economic and social rights were not taken seriously and were subordinated to civil and political rights. ${ }^{10}$ Few states included economic and social rights in their constitution and legislation to make these rights is enforceable." Some scholars also perceived that economic and social rights are non-justiciable rights. ${ }^{12}$ In his article on Against Positive Rights, Cass Sunstein argued that inserting social rights in the new constitution of post-communist European States 'was a large mistake'.13 The government should not be forced to interfere the free market. Besides, there is also an opinion which believe that social rights are unenforceable by courts because they lack bureaucratic and policy tools. ${ }^{14}$

In the 1970s, jurisprudence on justiciability of economic and social rights started to grow. In 1972, for instance, the German Constitutional Court granted the right to free choice of an occupation in the universities. ${ }^{15}$ In the same year, the European Commission of Human Rights emphasized the importance of the

9 Philippa Venning, "Determination of Economic, Social and Cultural Rights by the Indonesian Constitutional Court," Australian Journal of Asian Law 10, no. 1 (October 2008): 100-132.

10 Justice Richard J. Goldstone, "Foreword," in Courting Social Justice: Judicial Enforcement of Social and Economic Rights in Developing World, ed. Varun Gauri and Daniel M Brink (Cambridge: 2008), vii.

11 Goldstone, "Foreword," vii.

12 Galligan use the term "unsuited for adjudication" to explain "non-justiciable". See D.J. Galligan "Review Work: Discretionary Powers: A Legal Study of Official Discretion," The Cambridge Law Journal 46, no. 3 (November 1987): 241, https://www.jstor.org/stable/4507090.

13 Cass R. Sunstein, "Against Positive Rights, in Western Rights? Post-Communist Application," in Comparative Constitutional Law, ed. Andrass Sajo (New York: Foundation Press, 1996) 1483.

14 Sunstein, "Against," 1483.

15 Numerus Clausus I Case (1972), 33 BverfGE 303. see also Malcolm Langford, "The Justiciability of Social Rights: from Practice to Theory" in Social Rights Jurisprudence: Emerging Trends In International And Comparative Law ed. Malcolm Langford (Cambridge: 2008), 6. 
state to respect the individual's home. ${ }^{16}$ A decade later, the Indian Supreme Court ordered the municipality to fulfill the right to water. ${ }^{17}$ Since then the justiciability of economic and social rights overgrew in countries which witnessed democratic revolutions (South Africa, Eastern Europe, Latin America) and countries inspired by the Indian experiences (South Asian Countries). ${ }^{18}$

The development on the justiciability of ES rights also changed the direction of the scholarly debate. The dynamic expansion of economic and social rights in practice has altered the opinion that ES rights are not justiciable. This includes Cass Sunstein who asserted that, after witnessing the South African Constitutional Court rendered a decision on Grootboom case, the constitutional court approach stands as a powerful rejoinder to who have contended that socio-economic rights do not belong in a constitution. ${ }^{19}$ While there is a significant change concerning to the justiciability of ES rights, debate on whether economic and social rights are judicially enforceable still far from ended.

\section{III.VARIOUS INTERPRETATIONS REGARDING ECONOMIC AND SOCIAL RIGHTS AND PROBLEM OF THEIR JUSTICIABILITY}

A debate over justiciability cannot be separated from the doctrine of separation of powers. The principle of separation of powers suggests that the duty of the judiciary merely interpret and apply the law. A judicial institution does not make laws. The law-making function is in the hand of the legislative.

The question is how far the court can interpret the law? Should the court consistently loyal to the texts of the laws, or can the court interpret the law beyond the texts? How if the court interpretation alters the meaning of the law created by the legislature? Is the court the right avenue to resolve matters which impact public policy such as how the government should allocate the funding for education?

\footnotetext{
Case 4560/70. See also Case 5727/72 and Langford, "The Justiciability," 6.

7 Langford, "The Justiciability," 6.

18 Langford, "The Justiciability," 8.

19 Government of the Republic of South Africa v. Grootboom and others 2000 (11)BCLR 1169 (CC). See also Bertrand G. Ramcharan, Judicial Protection of Economic, Social and Cultural Rights: Cases and Materials, The Raoul Wallenberg Institute Human Rights Library 22, (Boston: Martinus Nijhoff, 2005), 297-336.
} 
The justiciability of economic and social rights focuses on the issue of whether a court is the right avenue to enforce such rights. Three conceptions often used to argue that economic and social rights are non-justiciable rights. First, the nature of economic and social rights is different from civil and political rights. ${ }^{20}$ Second, the problem of legitimacy which essentially questions the court legitimacy in dealing with economic and social policy. ${ }^{21}$ The third is about the court institutional capacity in resolving issues related to economic and social rights. ${ }^{22}$ The following part will examine these three different conceptions and prove that such notion mislead.

Are economic and social rights different from civil and political rights? There are perception that economic and social rights are positive rights which require intense involvement of the state to fulfil these rights. ${ }^{23}$ Civil and political rights, on the other hand, are negative rights which prevent the state's participation in the enjoyment of these rights. Since economic and social rights are perceived as positive rights, the involvement of the executive is the most appropriate avenue, not the involvement of the court. This is because the court has neither "purse nor sword." ${ }^{24}$ The State specifically the government and the legislature are the institutions which have the purse and the sword to implement ES rights. It possesses the necessary state apparatus and funding to implement ES rights. While this view sounds good, it can be misleading. Both civil political rights and economic and social rights are positive and negative rights to a certain extent. ${ }^{25}$ This is because the enforcement of both categories of rights needs states involvement. To implement ES rights and $\mathrm{CP}$ rights, the state often involves ensuring that these rights are fully implemented. On

20 Langford, "The Justiciability" 30.

21 Jeff King, Judging Social Rights (Cambridge University Press, 2012),152.

22 Langford, "The Justiciability," 211.

23 Langford, "The Justiciability," 30.

24 Alexander M. Bickel, The Least Dangerous Branch:The Supreme Court at the Bar of Politics (Bobbs-Merrill Company, 1962). See also Kevin J. Mitchell, "Neither Purse nor Sword: Lessons Europe Can Learn om American Courts' Struggle for Democratic Legitimacy," Case Western. Reserve. Journal of. International Law 38 (2007): 653.

25 Aoife Nolan, Bruce Porter and Malcolm Langford, "The Justiciability of Social and Economic Rights: An Updated Appraisal" (A CHRGJ Working Paper No. 15, 2020), 17, https://www.researchgate.net/publication/228275150_ The_Justiciability_of_Social_and_Economic_Rights_An_Updated_Appraisal/link/574089c108ae298602eba445/ download. 
the other hand, when the people have enjoyed these rights, the state cannot interfere the enjoyment of these rights.

In addition, economic and social rights are often viewed as vague and resource-dependent. ${ }^{26}$ They are perceived as vague because economic and social rights are difficult to be measured. Right to the highest attainable standard of health, for instance, is difficult to be measured when it is considered fulfilled. While it may be true that it is difficult to measure the fulfilment of ES rights quantitatively, there are specific criteria such as treatment and control to an epidemic, infant mortality and environmental hygiene to measure its fulfilment. ${ }^{27}$ Some civil and political rights such as the right to liberty and the right to human dignity can also be vague as they are difficult to be quantitatively measured..$^{28}$

Regarding to resource-dependent, the realization of economic and social rights such as the right to housing often demands significant financial resources and budget allocation. As it requires substantial financial resources, the realization of economic and social rights should be the government domain and not the judiciary.

Considerable financial resource is also required to implement civil and political rights. To implement right to vote in a general election, for example, significant funds is also needed. So, both civil and political rights and economic and social rights can be very resources dependent in particular circumstances.

Is it appropriate for a court to deal with economic and social rights? This question is related to two principles: the legitimacy and separation of power. Is a court legitimate to deal with economic and social policy? Judges are lack of democratic legitimacy. This is because they are not directly elected by the people. ${ }^{29}$ Economic and social policy should be the domain of elected representative of the people and not the province of a less democratic institution..$^{30}$ While it may be true that economic and social right should be the domain of

\footnotetext{
Bickel, The Least Dangerous. See also Mitchell, "Neither Purse Nor Sword."

Bickel, The Least Dangerous. see also Mitchell, "Neither Purse Nor Sword."

Nolan, Porter, Langford, "The Justiciability," 17.

King, Judging Social Rights, 152-3.

King, Judging Social Rights, 152-3.
} 
elected representative of the people, however, the judiciary has significant role to enhance democratic governance by reviewing the government decisions. ${ }^{31}$ The democratic legitimacy of judicial review is to ensure that the majoritarian decision making does not violate the right of minorities.

In addition, there is an assertion that the involvement of the judiciary in dealing with economic and social right is violating separation of powers. ${ }^{32}$ This is because formulating and executing economic and social policy is the domain of the executive. The work of the court is to enforce the law and not to develop or to execute the social policy. If the court involves in developing or executing policy, it, therefore, violates the separation of powers.

While adopting separation of powers is important, such a principle should be implemented together with other principles such as the rule of law and constitutional supremacy. The role of the court, based on the rule of law and constitutional supremacy, is to ensure all right are subject to effective remedy and provisions in the constitution are consistently applied.33

Does a court have the capacity to protect economic and social rights? Protecting economic and social rights is often closely related to formulating policy on economic and social rights. The important question is whether the court is the right institution to formulate such policy. This question is related to the assertion that judges lack comprehensive information and necessary expertise in settling cases related to economic and social rights. ${ }^{34}$ This is because court rulings are largely based on the evidence presented in the court proceedings. There is a possibility that there are other important factors that are not presented before the courts. Unfortunately, the court does not consider factors beyond what presented before the Court. As a result, courts are not sufficiently informed when adjudicating economic and social rights. 35

\footnotetext{
${ }^{11}$ King, Judging Social Rights, 152-3.

32 King, Judging Social Rights, 169.

33 Richard Bellamy, Political Constitutionalism: A Republican Defence Of The Constitutionality of Democracy, (Cambridge: 2007), 53.

34 King Judging Social Rights, 248.

35 Nolan, Porter, Langford, "The Justiciability," 17.
} 
When deciding cases related to economic and social rights, the expertise of the judges is not necessarily dealing with the nature of the policy rather it is about the expertise of judges to review the policy of the government against the requirement of the law, such expertise which already embedded in every judge. ${ }^{36}$

Furthermore, the problem of polycentric often become the reason why the court should not adjudicate economic and social rights. Polycentric is a situation where a judicial decision will have a complex impact that will extend beyond the parties and the factual situation before the court. ${ }^{37}$ The court is not the proper avenue to make polycentric decisions because adjudication is more adversarial process which applies solely to disputing parties..$^{8}$ Besides, there is limitation regarding the types of evidence presented before the court.

In fact, in some cases, the judiciary may provide better consideration of the competing rights of those who do not have access to political decision-making process. ${ }^{39}$ It may address an impact of policies that were not foreseen by the government and may reveal alternative remedies that were not considered by the legislature or executive. ${ }^{40}$

\section{VARIOUS APPROACHES IN PROTECTING ECONOMIC AND SOCIAL RIGHTS: SOME COUNTRIES EXPERIENCES}

Different countries may adopt different approaches to protecting economic and social rights. The first approach believes the fulfilment of economic and social rights is in the hand of the government. It is the government's responsibility -not the judiciary to fulfil these rights. In other words, economic and social rights are not judicially enforced. This approach is commonly called a nonjusticiable rights approach because these rights cannot be defended before judicial institution. It is the government duty to guarantee the enjoyment of these rights through issuing public policies.

\footnotetext{
Nolan, Porter, Langford, "The Justiciability," 17.

King, Judging Social Rights, 189.

38 King, Judging Social Rights, 189.

39 King, Judging Social Rights, 165.

40 King, Judging Social Rights, 165.
} 
The second approach to a certain extent is contradictory with the first approach in a way that based on this approach the judicial institutions such as the supreme court or the constitutional court is the most appropriate avenue to defend economic and social rights. This approach is called as justiciable rights as the judicial institution can enforce these ES rights.

The Hungarian Constitution, ${ }^{41}$ for instance, explicitly mentions that economic and social rights are justiciable. Article $70 \mathrm{~K}$ of the Hungarian Constitution stipulates: "Claims arising from infringement on fundamental rights, and objections to the decisions of public authorities regarding the fulfilment of duties may be brought before a court of law." The phrase "...can be brought before a court of law" guarantees economic and social rights, as part of fundamental rights, are justiciable. South Africa Constitution also guarantees that ES rights have been the subject of full judicial proceedings before the South African Constitutional Court.42

Third, other country constitution such as the Philippines Constitution does not expressly declare that ES rights to be justiciable. The Philippines Constitution states that social justice and human rights provisions are intended to be directive principles to guide government policy and only judicially considered if enacted in legislation. ${ }^{43}$ The Supreme Court of the Philippines, however, have held ES rights to be justiciable. ${ }^{44}$ The judicial approach in the Philippines can be categorized into judicially enforceable rights as the courts have the final say. ${ }^{45}$

Fourth, the Canadian and the UK Constitutions adopt other different models. Canada's Charter of Rights adopts notwithstanding clause. This means the Charter of Rights permits parliament or a provincial legislature to adopt legislation to

${ }_{41}$ Constitution of the Republic of Hungary, Article $70 \mathrm{~K}$.

42 South Africa Constitution 1996 Part II.B.3.b.

43 Article XIII of The 1987 Philippines Constitution states that social justice and human rights provisions are intended to be directive principles to guide government policy and only judicially considered if enacted in legislation.

44 The Philippines Supreme Court, in Oposa v Factoran GR, has held that the rights to a balanced and healthful ecology are judiciable without enacting legislation. In certification of the Constitution of the Republic of South Africa judgment, the Court declared that socio-economic rights are clearly justiciable rights in Diane A. Desierto, "Justiciability of Socio-Economic Rights: Comparative Powers, Roles, and Practices in the Philippines and South Africa," Asian Pacific Law and Policy Journal 11, no 138 (2009): 151.

45 Mark Tushnet, "State Action, Social Welfare Rights, and the Judicial Role: Some Comparative Observations," Chicago. Journal. International Law 3, no. 2 (2002): 449, https://chicagounbound.uchicago.edu/cgi/viewcontent. cgi?article $=1442 \&$ context $=$ cjil. 
override Section 2 of the Charter (containing fundamental rights) and Sections 7 to 15 of the Charter (containing the right to life, liberty and security, freedom from unreasonable search and seizure the right to equality etc.). This limitation should be expressly mention in the law and not subordinate legislation. ${ }^{46}$

UK Courts interpret statutes to be consistent with the European Convention on Human Rights if they can lawfully do so. In case the statute is inconsistent with the Convention, the Court will state that the statute is incompatible with the Convention. ${ }^{47}$ In such situation, the government is authorized to response in various ways such as modifying, introducing or doing nothing. $4^{8}$ The possibility of the government to respond and revise the court's constitutional rulings makes this approach as a weak form of judicial review ${ }^{49}$ as the government response and not the court decisions is the final judgement.

Fifth, India and Ireland adopt another different method. India and Ireland have included economic and social rights in their constitutions that are expressly stated to be not justiciable..$^{\circ}$ They act as guiding principles which mean that these principles guide the court in interpreting statutes of the legislature. This type of judicial review is classified as super weak form review. ${ }^{51}$

In summary, the approaches on the determination of economic and social rights can be broadly categorized into three main models namely: judicially enforceable rights, a tool to test the reasonableness of government policy-making and non-justiciable policy guidelines. These three models also reflect types of judicial review i.e. the strong-form judicial review, weak form of judicial review (as explained by Mark Tushnet) ${ }^{52}$ and super-weak form of judicial review. ${ }^{33}$

\footnotetext{
${ }_{46}$ Laurence Brosseau and Marc-Andre Roy, "The Notwithstanding Clause of the Charter" (A Background Paper, Library of Parliament, 7 May 2018), https://lop.parl.ca/staticfiles/PublicWebsite/Home/ResearchPublications/ BackgroundPapers/PDF/2018-17-e.pdf accessed 27 January 2020. Notwithstanding Clause is mentioned in Section 33 of the Canadian Charter of Rights and Freedoms.

47 Tushnet, "State Action," 449.

48 Tushnet, "State Action," 449.

49 Tushnet, "State Action," 449.

50 The Indian Constitution, Article 37 and The Ireland Constitution, Article 45.

51 Mark Tushnet, "State Action,"453.

52 Mark Tushnet, Weak Courts, Strong Rights: Judicial Review and Social Welfare Rights in Comparative Constitutional Law (Princeton University Press, 2009).

53 Venning, "Determination of Economic," 102. See also Rosalind Dixon, "Creating Dialogue About Socioeconomic Rights: Strong-Form Versus Weak-Form Judicial Review Revisited," International Journal of Constitutional Law 5, no. 3 (2007): 402.
} 


\section{JUDICIAL APPROACH OF ECONOMIC AND SOCIAL RIGHTS IN INDONESIA}

The year 1999 marked a great socio-political movement in Indonesia-called reformasi. The reformasi was followed by substantial amendments of the 1945 Indonesian Constitution. The amended Constitution introduced two new judicial institutions namely Judicial Commission (Komisi Yudisial) and Constitutional Court (Mahkamah Konstitusi) and added another representative institution, i.e. Regional Representatives Council (Dewan Perwakilan Daerah) beside the already existing People Representative Council (The DPR).

The amended Constitution also embodies a liberal democratic system with some degree of separation of power and a swathe of economic, social and cultural rights. ${ }^{44}$ The new Constitution inserted a new, specific Chapter on Human Rights. The Human Rights Chapter provides comprehensive provisions on civil-political rights, economic social and cultural rights and the right to development. Concerning provisions on economic and social rights, the new Constitution mentions the right to improve one's welfare, ${ }^{55}$ the right to a healthy environment and receive medical care ${ }^{56}$ and social security. ${ }^{57}$ Also, the state shall prioritize the budget for education to a minimum of 20 per cent of the state budget..$^{8}$

Under Article 33, the economy shall be organized as a common endeavor, sector of production important for the country and which affect the life of the people shall be under the power of the state and, in particular, the land, water and natural riches shall be controlled by the state and shall be utilized for the greatest benefit of all people. While there are more provisions regarding economic and social rights, there is no provision which explicitly states that such rights are justiciable.

\footnotetext{
54 Tim Lindsey, "Devaluing Asian Values, Rewriting Rule of Law" in Asian Discourses of Rule of Law: Theories and Implementation of Rule of Law in Twelve Asian Countries, France and the US," ed. Randall Peerenboom (London, New York: Routledge Taylor and Francis Group, 2004), 296, 31.

55 The amended 1945 Indonesian Constitution, Article $28 \mathrm{C}$.

56 The amended 1945 Indonesian Constitution, Article $28 \mathrm{H}$ (1).

57 The amended 1945 Indonesian Constitution, Article $28 \mathrm{H}$ (3).

$5^{8}$ The amended 1945 Indonesian Constitution, Article 31 (4).
} 
This Part will examine the justiciability of economy and social rights in Indonesia post the 1999-2002 constitutional amendments. The author acknowledges that economic and social rights are vast topics. It is not possible to analyze all the court rulings regarding economic and social rights in this paper considering that the Court decided over a thousand constitutional review cases so far. Therefore, this paper will focus on analyzing four constitutional court decisions, in which in the author's opinion, have significant impact in protecting economic and social rights. The four Constitutional Court decisions are the judicial review of Law on Electricity, ${ }^{59}$ judicial review of Law on Water Resource, ${ }^{60}$ judicial review of Law on National Educational System ${ }^{61}$ and judicial review of Law on National Budget. ${ }^{62}$ In examining these four constitutional court rulings, this Part will utilize the three judicial approaches mention above i.e. judicially enforceable rights, a tool to test the reasonableness of government policy-making and non-justiciable policy guidelines. ${ }^{63}$ These three models in the author's opinion, can be used as a method to explain the Court's approach in deciding cases related to ES rights.

\subsection{Judicial Review of Law No 20/2002 on Electricity: Judicially Enforceable yet Lack of Consideration?}

Petition for judicial review of Law on Electricity ${ }^{64}$ was filed by groups of people (consisted of NGO's and Human rights advocates) who argued that substances contained in some provisions of the Law were inconsistent with Article 33 of the Constitution. Article 33 paragraph (3) of the Constitution stipulates "Land, waters and the natural resources contained therein shall be utilized for the greatest well-being of the people."

59 Judicial Review of Electricity Law, Decision of Constitutional Court No 001-021-022/PUU-1/2003 (The Constitutional Court of the Republic of Indonesia 2003).

6o Judicial Review of Education System Law, Decision of Constitutional Court No 058-059-060-063/PUU-II/2004 and 008/PUU-III/2005 (The Constitutional Court of the Republic of Indonesia 2005).

61 Judicial Review of National Budget Law, Decision of Constitutional Court No 011/PUU-III/2005 (The Constitutional Court of the Republic of Indonesia 2005).

62 Judicial Review of National Budget Law, Decision of Constitutional Court No 012/PUU-III/2005 (The Constitutional Court of the Republic of Indonesia 2005).

63 Dennis Davis, "Socio-Economic Rights: Has the Promise of Eradicating the Divide between First and Second Generation Rights Been Fulfilled?" in Comparative Constitutional Law, eds Rosalind Dixon and Tom Ginsburg (Cheltenham: Edward Elgar Publishing, 2011), 519, 528.

64 Judicial Review of Electricity Law, Decision of Constitutional Court No 001-021-022/PUU-1/2003 (The Constitutional Court of the Republic of Indonesia 2003). 
The petitioners contended that the provisions of the Law which were being challenged before the Court had reduced or even eliminated State's control over natural resources stipulated in Article 33 of the Constitution. That was because the Law opened the possibility of privatization in the electricity sector. ${ }^{65}$ In this regard, the petitioners questioned 'the roles of state to control' natural resources for the greatest well-being of the people. The petitioners also concerned that the creation of this law was based on the idea of the privatizing and liberalizing economic sector, which is actually the main feature of the free market economy. ${ }^{66}$

The Court declared that state control, as stated in Article 33, should be interpreted that the state had the power to control important sectors of production. The state also had a duty to protect ES rights, including the electricity sector in order to provide social justice by ensuring the availability, even distribution and affordability of important products. ${ }^{67}$ In this case, the Court broadly interpreted the phrase "shall be under State control" into five categories namely the power of the state to make policy (mengadakan kebijakan), to manage (tindakan pengurusan), to regulate (pengaturan), to participate (pengelolaan) and to supervise (pengawasan) important sectors of production for the greatest well-being of the people. ${ }^{68}$ The Court believed that the right to electricity was important for the public in general. Therefore, the Court declared that private ownership of the electricity sector was not in line with the people's best interests. ${ }^{69}$ The Court found the provisions that introduce the concept of competition and unbundling was in contradiction with Article 33 (2) of the Constitution. $7^{\circ}$ The Court even went further by declaring that the Law had no longer

65 Law of the Republic of Indonesia No. 20/2002 on Electricity, Article 8(2).

66 Law of the Republic of Indonesia Article 16 of Electricity Law.

67 Judicial Review of Electricity Law, Decision of Constitutional Court No 001-021-022/PUU-1/2003 (The Constitutional Court of the Republic of Indonesia 2011), 330.

68 Judicial Review of Electricity Law, Decision of Constitutional Court No 001-021-022/PUU-1/2003 (The Constitutional Court of the Republic of Indonesia 2003), 334.

69 Judicial Review of Electricity Law, Decision of Constitutional Court No 001-021-022/PUU-1/2003 (The Constitutional Court of the Republic of Indonesia 2003), 349.

70 Judicial Review of Electricity Law, Decision of Constitutional Court No 001-021-022/PUU-1/2003 (The Constitutional Court of the Republic of Indonesia 2003), 349. 
possessed its legally binding power in its entirety..$^{71}$ That was because the provisions that had been declared unconstitutional were "the heart and soul" of the Law. Hence, if the losing of legally binding power were applied only to those provisions that had been declared unconstitutional, such an approach would lead to legal uncertainty..$^{2}$

Prior to the decision, the Court had heard the government's arguments emphasizing that State-owned enterprise (PLN) could not fulfil the electricity demand. ${ }^{73}$ According to the government, competition will create more opportunity for other enterprises to provide electricity in a more efficient and transparent way. The Court also considered other countries experience in regard to privatisation. ${ }^{74}$ The failure of privatisation, however, was more convincing, so the Court concluded that privatisation often fails to guarantee the availability, the affordability and even distribution of electricity. The legal reasoning of the Court was very general and unpersuasive.

The electricity case illustrates that the Constitutional Court conducted a strong judicial review, as the Court invalidated the legislative statute entirely. This case also shows that the right to electricity had been considered as an important production sector, as stated in Article 33. Therefore, it can be impliedly deduced that in the opinion of the Court that this right is judicially enforceable.

In this case, the Court also entered the area of policy-making. It invalidated in its entirety the product of a democratically elected parliament and ordered the revival of the previous law. The Court has gone beyond the South African 'reasonableness of government policy test'. 75 The Court also did not provide balanced consideration regarding privatisation policy decision. While the Court considered the experience of countries where

${ }_{71}$ Judicial Review of Electricity Law, Decision of Constitutional Court No 001-021-022/PUU-1/2003 (The Constitutional Court of the Republic of Indonesia 2003), 350.

72 Judicial Review of Electricity Law, Decision of Constitutional Court No 001-021-022/PUU-1/2003 (The Constitutional Court of the Republic of Indonesia 2003), 350.

73 Judicial Review of Electricity Law, Decision of Constitutional Court No 001-021-022/PUU-1/2003 (The Constitutional Court of the Republic of Indonesia 2003), 337.

74 Judicial Review of Electricity Law, Decision of Constitutional Court No 001-021-022/PUU-1/2003 (The Constitutional Court of the Republic of Indonesia 2003), 186-7.

75 South African Constitutional Court decision on Grootboom. 
privatisation failed, it did not consider other countries experience where privatisation worked well. The Court did not sufficiently consider data showing the poor performance of the existing state own company. In this case, the Court did not sufficiently show its ability to deal with complex issues such as privatisation. The Court seems to lack of institutional competence to determine complex issues.

\subsection{Judicial Review of Law No. 7/2004 on Water Resource: Judicially Enforceable yet Going Too Far?}

The 2004 Water Resource Law decentralizes water sector management and allows participation from private sectors. ${ }^{76}$ The Law acknowledges the importance of Article 33 of the Constitution, which clearly stipulates that water shall be under the state control and shall be utilized for the greatest well-being of the people. The Law determines that water for daily need is not subject to a fee or license. ${ }^{77}$ The government has the power to issue a license to exploit water to community and business, but in doing so, it must consider the water management scheme. ${ }^{78}$

Several NGOs and individuals filed petitions to the Constitutional Court. The petitioners stated that the Water Law was in contradiction with Article 33 (2) of the Constitution.79 The petitioners claimed that the Law had changed the social function of water into commercial purpose (profit oriented) ${ }^{80}$ The Law would potentially disregard the people's right to water. As a result, the purpose of Article 33 (2) 'the water shall be utilized...for the greatest well-being of the people' would never be satisfied.

In its ruling, the Court declared that the Water Resource Law had fulfilled the right to water as stated in the Constitution. ${ }^{8_{1}}$ This was because

6 Law of the Republic of Indonesia, Article 11 of Law on Water Resource.

77 Law of the Republic of Indonesia, Article 7 of Law on Water Resource.

78 Law of the Republic of Indonesia, Article 9, 11 of Law on Water Resource.

79 Judicial Review of Water Resources Law, Decision of Constitutional Court No. 058-059-060-063/PUU-II/2004 and 008/PUU-III/2005 (The Constitutional Court of the Republic of Indonesia 2005).

80 Judicial Review of Water Resources Law, Decision of Constitutional Court No. 058-059-060-063/PUU-II/2004 and 008/PUU-III/2005 (The Constitutional Court of the Republic of Indonesia 2005), 541.

81 Judicial Review of Water Resources Law, Decision of Constitutional Court No. 058-059-060-063/PUU-II/2004 and 008/PUU-III/2005 (The Constitutional Court of the Republic of Indonesia 2005), 495. 
the government, through its power to grant a permit, still hold power to control the important sector of production. As to the meaning of "state's control," the ruling referred to the previous court decision (i.e. judicial review on Electricity Law) that interpreted state control into five different activities such as: policy making, maintaining, managing, granting permits and supervising. ${ }^{82}$ Accordingly, the Court rejected the petitions and maintained the constitutionality of the Law. Nevertheless, although the Court rejected petitions, it did not overrule the whole arguments of the petitioners. The Court acknowledged that the Law might be interpreted in such a way so as to make it contradictory to the Constitution.

But, instead of declaring the Law unconstitutional, the majority of justices was of the opinion that the Law should be considered conditionally constitutional. ${ }^{83}$ This means that the constitutionality of the Law was subject to a certain condition. The Law would only be considered constitutional as long as its application was in line with the Court's interpretation elaborated in this decision. Consequently, if (in the future) there is allegation that the Law has been applied differently, the constitutionality of the Law could be reviewed for second time before the Court. The Court provided a test of the reasonableness of the government policy by elaborating all necessary conditions that should be fulfilled to maintain the constitutionality of the Water Resources Law. The court guidance in this case includes: private providers must fulfil the right to water; private providers do not charge an expensive fee to people for their daily need and small-scale farming; the determination of price must be consulted with the community; the government must prioritize its responsibility to provide drinking water. ${ }^{84}$

The Court's ruling on the Water Resources Law illustrates several important features: first, the Court does not automatically invalidate

\footnotetext{
Judicial Review of Water Resources Law, Decision of Constitutional Court No. 058-059-060-063/PUU-II/2004 and 008/PUU-III/2005 (The Constitutional Court of the Republic of Indonesia 2005), 495.

${ }_{83}$ Judicial Review of Water Resources Law, Decision of Constitutional Court No. 058-059-060-063/PUU-II/2004 and 008/PUU-III/2005 (The Constitutional Court of the Republic of Indonesia 2005), 495.

84 Judicial Review of Water Resources Law, Decision of Constitutional Court No. 058-059-060-063/PUU-II/2004 and 008/PUU-III/2005 (The Constitutional Court of the Republic of Indonesia 2005), 493-494.
} 
the Law. The Court's approach, in this case, is different from the Court approach in Electricity Law where the Court nullify the Law in its entirety. In Water Resources Law case, the Court refrain itself from nullifying the Water Resources Law. The Court, instead, provides conditions that should be fulfilled by the government to determine the constitutionality of the Law. While the Court approach, in this case, seems softer compared to the Court approach in Electricity Law, the Court actually directs the government and the lawmaker regarding the principles that they should insert in the regulations derived from this Law. Second, this decision asserts that the right to water is judicially enforceable.

The Court further provides guidance for the government in issuing the implementing regulations. Such guidance, to a certain extent, has entered policy making, which is the domain of the legislature as the lawmaker. Finally, this case shows a new approach used by the Court. The Court introduces a new type of decision, namely conditionally constitutional. The conditionally constitutional decision is not in line with the 'final and binding' nature of the Constitutional Court decision since a conditional decision opens a possibility that the Law can be submitted again to the Court for further review.

In 2013, a petition for judicial review of Water Resources Law was submitted again by Groups of the people and individuals. The petitioners claimed that the Law had allowed monopoly. It also tended to regulate water for commercial interests. ${ }^{85}$ The petitioners also claimed that the Law had reduced the responsibility of the state to fulfil the need of water ${ }^{86}$ The government responded that the Law aimed to improve the accessibility of community to water. The Law, according to the government, had also sufficiently protected the right to water and prevented the privatisation. The government further stated that from 2010 up to 2015, there was a

85 Judicial Review of Water Resources Law, Decision of Constitutional Court No 85/PUU-XI/2013 (The Constitutional Court of the Republic of Indonesia 2013), 28.

86 Judicial Review of Water Resources Law, Decision of Constitutional Court No 85/PUU-XI/2013 (The Constitutional Court of the Republic of Indonesia 2013), 31. 
significant increase from 34 municipalities to 116 municipalities that get the clean water programs. ${ }^{87}$

In reaching the decision, the Court examined seven implementing regulations that had been issued by the government since the Court decision in 2004. In the decision, however, the Court did not explain in which specific part of the seven implementing regulations contradicted with Court guidance. The Court in very general nature declared that the implementing regulations were not in line with the guidance of the court stated in its previous decision. ${ }^{88}$ The Court then invalidated the Law on Water Resources for its entirety because based on the consideration that the invalidated provisions were 'the heart' of the Law. ${ }^{89}$

This decision shows the Court tendency to adopt strong form of judicial review approach as the Court invalidated not only particular provisions of the Law but the Law in its entirety. The Court once again entered the policy making by invalidating in its entirety the product of a democratic institution. The Court re-imposed the old law, namely Law 11/1974. The Water Resources Law decision shows justiciability of the constitutional provisions concerning important sectors. The Court can decide matters related to Article 33 of the Constitution. In this case, the Court had acted beyond its constitutional jurisdiction. The Court jurisdiction is to review an act against the Constitution. But as can be seen in this case, the Court reviewed the Law by scrutinizing whether implementing regulations derived for this Law consistent with the court's guidance as reflected in the ruling. In other words, the constitutionality of the Water Resources Law depended on whether the implementing regulations satisfied the Court guidance. One may question the finality of the Constitutional Court decision as this exact same Law has been reviewed in the past by the same Court. But the Court

Judicial Review of Water Resources Law, Decision of Constitutional Court No 85/PUU-XI/2013 (The Constitutional Court of the Republic of Indonesia 2013), 80.

88 Judicial Review of Water Resources Law, Decision of Constitutional Court No 85/PUU-XI/2013 (The Constitutional Court of the Republic of Indonesia 2013), 138-9.

89 Judicial Review of Water Resources Law, Decision of Constitutional Court No 85/PUU-XI/2013 (The Constitutional Court of the Republic of Indonesia 2013), 143. 
decisions, in this case, is actually a consequence of the Court previous decision which provide a conditional decision.

Six years after the invalidation of the Water Resource law, a new law concerning water resources was finally introduced on October 15, 2019.90 This newly enacted law implements the Court's previous decisions on judicial review of Water Resource Law. It contains the right to water, water management, water licencing system and criminal sanctions in case there is a violation against the provisions of this law. So far, there is no petitions submitted to the Court requesting judicial review regarding the existence of this new law.

\subsection{Right to Education: Judicial review of Law on National Education System and the 2005 State Budget Law.}

In judicial review of Law on National Education System, the petitioner claimed that elucidation of Article 49 of the National Education System Law violated Article 31 (4) of the Constitution. ${ }^{91}$ That was because the elucidation stated that the allocation of 20 percent of the State Budget to the educational sector could be conducted gradually. The petitioners argued that Article 31 (4) of the Constitution implied that the government's obligation to allocate at least 20 percent could be done gradually. ${ }^{92}$ Therefore, the petitioners believed that the elucidation of Article 49 was contradictory to the Constitution. The petitioners also argued that Article 49 was not in line with the nature of elucidation, i.e. explaining the norm of the Law provisions and not adding new norms. The Court agreed with the petitioners' arguments and declared that the obligation of the government as required by the Constitution could not be deferred. The Court granted the petition in part by striking down the elucidation for being repugnant to the Constitution.

9o Law of the Republic of Indonesia, No. 17 of 2019 on Water Resource.

${ }^{11}$ Judicial Review of National Education System Law, Decision of Constitutional Court No. 011/PUU-III/2005 (The Constitutional Court of the Republic of Indonesia 2005).

92 The Constitution of the Republic of Indonesia, Article 31 (4): The state shall prioritize the budget for education to a minimum of $20 \%$ of the State Budget and the Regional Budget to fulfill the needs of implementation of national education. 
The petitioners of the National Education System Law filed a similar petition to the Constitutional Court. In this case, the petitioners challenged the 2005 Law on National State Budget, which allocated 7 percent to the educational sector. 93 The Court ruled that the 2005 Law on National State Budget violated the Constitution because it failed to meet the 20 percent requirement of State Budget that must be allocated for the education sector.

Nevertheless, the Court further considered that if the whole Law be unconstitutional, then the entire law would lose its legally binding power. In a such situation, the Court took into account two possible consequences. First, the government should reformulate the state budget so as to meet the minimum allocation of 20 percent of the State Budget for education sector as required by the Constitution. If such reformulation was conducted, there would be a reduction in the budget allocation for other sectors. This might create legal uncertainty in budgetary and financial administration in the country.

Second, according to the Constitution, invalidation of State Budget Law would oblige the government to use the previous year's state budget.94 Unfortunately, in this case, the previous year's state budget for the educational sector was lower than the allocation for the educational sector in the current National State Budget.

In reaching the decision, the Court used 'categorical - proportionality approach'. ${ }^{55}$ The Court categorically determined whether Article 31 (4) of the Constitution has been infringed. The Court then determined whether such infringement was justified. In doing so, the Court proportionally considered and weighed the above consequences and possibilities. The Court declared that Article 31 (4) had been violated. The Court decided that the 2005 National Budget Law violated the Constitution. However, it was not necessary to declare the Law should lose its legally binding power entirely. That was because by

\footnotetext{
93 Judicial Review of State Budget Law, Decision of Constitutional Court No. 012/PUU-III/2005 (The Constitutional Court of the Republic of Indonesia 2005).

94 The 1945 Constitution of the Republic of Indonesia, Article 23 (3).

95 Stephen Gardbaum, "The Structure and Scope of Constitutional Rights," in Comparative Constitutional Law 388 , ed. Tom Ginsburg and Rosalind Dixon (Edward Elgar, 2011).
} 
doing so would create problems both in budgetary and financial administration and the possibility to have a lower budget allocation for the education sector. As a result, the Court declared the Law is inconsistent with the Constitution but it does not invalidate the Law entirely. The approach shows the Court careful consideration in deciding case which have a significant impact to the government and the people at large. The Court strategically decides this case with the expectation that the government will follow the Court ruling.

In the following year, a similar petition submitted to the Court claiming that the 2006 National Budget Law violated Article 31 (4) of the Constitution ${ }^{96}$ as there was only 9.1 percent of State Budget allocated for education sector. The petitioners argued that the government did not demonstrate good faith to fulfil both the provision in the Constitution as well as the decision of the Constitutional Court in the previous case. ${ }^{97}$ Constitutional Court declared that the 2006 State Budget to be null and void. The consequence was that the government and the parliament should adjust the 2006 State Budget during the midyear adjustment of the state budget, to comply with the constitutional provision..$^{8}$

Based on these two rulings, the Court provided a guideline for future cases. In case that state budget does not reach 20 percent allocation for education sector, the State Budget Law will be considered violates the Constitution. The Court, however, will consider the legal impact in examining those future cases. The Court will take into consideration the national economic condition and policies of the government and the parliament in reaching the decision.99

In this case, the Court continued using the proportionality principle to decide the case concerned. The Court considers whether the means employed by the government to promote its conflicting public policy are justified.

96 Judicial Review of National State Budget Law, Decision of Constitutional Court No. 026/PUU-IV/2006 (The Constitutional Court of the Republic of Indonesia 2006).

97 Judicial Review of National State Budget Law, Decision of Constitutional Court No. 026/PUU-IV/2006 (The Constitutional Court of the Republic of Indonesia 2006), 46-7.

98 Judicial Review of National State Budget Law, Decision of Constitutional Court No. 026/PUU-IV/2006 (The Constitutional Court of the Republic of Indonesia 2006), 95.

99 There is an incremental change in the allocation to educational sector. In 2004 there was 6.6 percent, 7 percent in $2005,8.1$ percent in 2006, 9.1 percent. 


\section{CONCLUSION}

The paper has shown that economic and social rights in Indonesia are judicially enforceable. This can be seen from the decisions of the Constitutional Court in judicial review cases of Electricity Law, Water Resource Law, National Education System Law and National Budget Law mentioned above in which the Court determined the constitutionality of these laws. The four cases of the judicial review showed how the Constitutional Court addressed economic and social rights issues. The Court which has the power to determine the constitutionality of legislative statutes may declare a provision of such statutes unconstitutional and lose their legally binding power if the Court finds they are inconsistent with or contrary to the Constitution.

In practice, however, the Court does not always "invalidate" the provisions of a statute even if the Court finds that such provisions are not in line with the Constitution. The Court, in some cases, refrains itself from "invalidating" the law even though the Court is of the opinion that the law is in contradiction with the Constitution. The Court, in such cases, will first take into account the possible impact of a decision which is invalidating a law -in terms of declaring a law or some provisions of a law unconstitutional and lose their legally binding power. The Court's decision on judicial review of Law on State Budget shows the Court tendency to consider potential negative consequences that may be involved if the Law declared losing its legally binding power. As a result, the Court does not automatically declare the National Budget Law is losing its legally binding power in spite of the fact that some provisions of the Law have been found contradictory to the Constitution. The Court instead suggests the lawmaker to fulfill its constitutional obligation, namely fulfilling 20 percent budget allocation for education at once.

In some other cases, as can be seen in judicial review of Law on Electricity and to some extent the judicial review of Law on Water Resources, the Court does not adequately consider other significant factors that may have significant impacts when the Court is reaching its decisions. The Court rulings in these two 
cases mentioned- above declare the Law was unconstitutional in its entirety or declared the Law conditionally constitutional. These two types of decisions have a significant impact because when the Court declared the Law unconstitutional in its entirety, the Court dismissed the legislative statute. When issuing conditional decisions, the Court direct the legislative by providing guidance that should be followed by the lawmakers when drafting the law. The Court in these two instances essentially goes beyond its constitutional jurisdiction. The Court has entered policy making function of the legislature. These types of court decisions can be beneficial or destructive depending how the Court exercise these powers. The adoption of these two approaches can be very beneficial particularly when exercising these powers, the Court is equipped by necessary competence and ample knowledge regarding the matters. the court decision may convey the voice of the minority, which may not be heard in the legislative process. In other words, the minority voice may be defended through the judicial process.

On the other hand, this significant power can be destructive if the Court does not use it appropriately. The use of this power without proper competence, knowledge and consideration may not only lead to the tensions with other branches of government but also negatively impact the people at large.

\section{BIBLIOGRAPHY}

Bellamy, Richard. Political Constitutionalism: A Republican Defence of the Constitutionality of Democracy. Cambridge University Press, 2007.

Brosseau, Laurence and Marc-Andre Roy. "The Notwithstanding Clause of

the Charter." A Background Paper, Library of Parliament, 7 May 2018, https://lop.parl.ca/staticfiles/PublicWebsite/Home/ResearchPublications/ BackgroundPapers/PDF/2018-17-e.pdf accessed 27 January 2020.

Bickel, Alexander M. The Least Dangerous Branch: The Supreme Court at the Bar of Politics. Bobbs-Merrill Company, 1962.

Davis, Dennis. "Socio-Economic Rights: Has the Promise of Eradicating the Divide between First and Second-Generation Rights Been Fulfilled?” In 
Comparative Constitutional Law, edited by Rosalind Dixon and Tom Ginsburg. Cheltenham: Edward Elgar Publishing, 2011.

Desierto, Diane A. "Justiciability of Socio-Economic Rights: Comparative Powers,

Roles, and Practices in the Philippines and South Africa." Asian-Pacific Law E Policy Journal 11 (2009), http://blog.hawaii.edu/aplpj/files/2011/11/ APLPJ_11.1_desierto.pdf.

Dixon, Rosalind. "Creating Dialogue About Socioeconomic Rights: Strong-Form

Versus Weak-Form Judicial Review Revisited." International Journal of Constitutional Law 5, no. 3 (2007).

Galligan, D.J. "Rewviw Work: Discretionary Powers: A Legal Study of Official Discretion." The Cambridge Law Journal 46, no. 3 (November 1987): 241, https://www.jstor.org/stable/450709o.

Gardbaum, Stephen. "The Structure and Scope of Constitutional Rights." In Comparative Constitutional Law, edited by Tom Ginsburg and Rosalind Dixon. Edward Elgar Publishing, 2011.

Goldstone, Justice Richard J. "Foreword." In Courting Social Justice: Judicial Enforcement of Social and Economic Rights in Developing World, edited by Varun Gauri and Daniel M Brink, 2008).

Government of the Republic of South Africa v. Grootboom and others 2000 (11)BCLR 1169 (CC).

Heymann, Jody, Aleta Sprague and Amy Raub. Advancing Equality: How Constitutional Rights Can Make a Difference Worldwide. Oakland: University of California Press, 2020.

International Commission of Jurist (ICJ). "Court and The Legal Enforcement of Economic Social and Cultural Rights: Comparative Experience of Justiciability.” A Report, International Commission of Jurist Publisher, 2008. https://www.refworld.org/docid/4a7840562.html.

Judicial Review of National Budget Law, Decision of Constitutional Court No oi1/ PUU-III/2005 (The Constitutional Court of the Republic of Indonesia 2005). Judicial Review of National Budget Law, Decision of Constitutional Court No 012/ PUU-III/2005 (The Constitutional Court of the Republic of Indonesia 2005). 
Judicial Review of National State Budget Law, Decision of Constitutional Court No. 026/PUU-IV/2006 (The Constitutional Court of the Republic of Indonesia 2006).

Judicial Review of Water Resources Law, Decision of Constitutional Court No. 058-059-060-063/PUU-II/2004 and 008/PUU-III/2005 (The Constitutional Court of the Republic of Indonesia 2005).

Judicial Review of Electricity Law, Decision of Constitutional Court No oo1-021022/PUU-I/2003 (The Constitutional Court of the Republic of Indonesia 2003). Judicial Review of Water Resources Law, Decision of Constitutional Court No 85/ PUU-XI/2013 (The Constitutional Court of the Republic of Indonesia 2013). Jackson, Vicki C., and Mark V. Tushnet. Comparative Constitutional Law. New York: Foundation Press, 1999.

King, Jeff. Judging Social Rights. London: University of College London, 2012. Langford, Malcolm. "The Justiciability of Social Rights: from Practice to Theory." In Social Rights Jurisprudence: Emerging Trends in International and Comparative Law, edited by Malcom Langford, Cambridge University Press, 2008.

Law of the Republic of Indonesia, Number 7 of 2004 on Water Resource.

Law of the Republic of Indonesia, Number 20 of 2002 on Electricity.

Law of the Republic of Indonesia, Number 20 of 2003 on National Education System. Law of the Republic of Indonesia on the 2005 State Budget.

Lindsey, Tim. "Devaluing Asian Values, Rewriting Rule of Law." In Asian Discourses of Rule of Law: Theories and Implementation of Rule of Law in Twelve Asian Countries, France and the US, edited by Randall Peerenboom. London: Routledge, 2004.

Mitchell, Kevin J. "Neither Purse nor Sword: Lessons Europe Can Learn om American Courts' Struggle for Democratic Legitimacy.” Case Western. Reserve. Journal of International Law 38 (2007).

Nolan, Aoife, Bruce Porter and Malcolm Langford. "The Justiciability of Social and Economic Rights: An Updated Appraisal.” A CHRGJ Working Paper No. 15, 2020. 
Numerus Clausus I Case (1972), 33 BverfGE 303.

Ramcharan, Bertrand G. Judicial Protection of Economic, social and Cultural Rights: Cases and Materials, The Raoul Wallenberg Institute Human Rights Library Volume 22. Boston: Martinus Nijhoff, 2005.

Scott, Graig and Patrick Macklem. "Constitutional Ropes of Sand or Justiciable Guarantees? Social Rights in a New South African Constitution.” University of Pennsylvania Law Review141, no.1 (November 1992), https://scholarship. law.upenn.edu/penn_law_review/voli41/iss1/2/.

Sunstein, Cass R. "Against Positive Rights, in Western Rights? Post-Communist Application." In Comparative Constitutional Law, edited by Andrass Sajo, 1996. The 1945 Indonesian Constitution.

The 1949 Constitution of the Republic of Hungary.

The 1987 Philippines Constitution.

The 1937 Constitution of Ireland.

The India Constitution.

The South African Constitution.

Tushnet, Mark. "State Action, Social Welfare Rights, and the Judicial Role: Some Comparative Observations." Chicago Journal of International Law 3, no. 2 (2002), https://chicagounbound.uchicago.edu/cgi/viewcontent. cgi article $=1442 \&$ context $=$ cjil .

Tushnet, Mark. "Weak Courts, Strong Rights: Judicial Review and Social Welfare Rights in Comparative Constitutional Law." 2009.

United Nations Human Rights, Office of the High Comissioner. "Key concepts on ESCRs-Are Economic, Social and Cultural Rights Fundamentally Different from Civil and Political Rights?" Accessed January 27, 2020. https://www.ohchr.org/EN/Issues/ESCR/Pages/ AreESCRfundamentallydifferentfromcivilandpoliticalrights.aspx.

Venning, Philippa. "Determination of Economic, Social and Cultural Rights by the Indonesian Constitutional Court." Australian Journal of Asian Law 10, no. 1 (October 2008). 